\title{
Review \\ Intermittent Fasting and Fat Mass: What Is the Clinical Magnitude?
}

\author{
Heitor O. Santos
}

check for

updates

Citation: Santos, H.O. Intermittent Fasting and Fat Mass: What Is the Clinical Magnitude? Obesities 2022, 2 , 1-7. https://doi.org/10.3390/ obesities 2010001

Academic Editor: Jürgen Vormann

Received: 23 November 2021

Accepted: 4 January 2022

Published: 7 January 2022

Publisher's Note: MDPI stays neutral with regard to jurisdictional claims in published maps and institutional affiliations.

Copyright: (c) 2022 by the author. Licensee MDPI, Basel, Switzerland. This article is an open access article distributed under the terms and conditions of the Creative Commons Attribution (CC BY) license (https:// creativecommons.org/licenses/by/ $4.0 /)$.
School of Medicine, Federal University of Uberlandia (UFU), Para Street, 1720, Umuarama. Block 2H, Uberlandia 38400-902, Minas Gerais, Brazil; heitoroliveirasantos@gmail.com

\begin{abstract}
Clinical studies addressing the benefits of intermittent fasting (IF) diets have evoked interest in the treatment of obesity. Herein, the overall effects of IF regimens on fat-mass loss are explained in a brief review through a recent literature update. To date, human studies show a reduction in fat mass from 0.7 to $11.3 \mathrm{~kg}$ after IF regimens, in which the duration of interventions ranges from two weeks to one year. In light of this, IF regimens can be considered a reasonable approach to weight (fat mass) loss. However, the benefits of IF regimens occur thanks to energy restriction and cannot hence be considered the best dietary protocol compared to conventional diets.
\end{abstract}

Keywords: intermittent fasting; fat mass; obesity; time-restricted feeding; weight loss

\section{Introduction}

Many types of intermittent fasting (IF) regimens have integrated therapeutic alternatives against health issues [1]. Religious, conventional, and modern protocols constitute IF regimens such as Ramadan, alternate-day fasting, and time-restricted feeding [2,3]; even skipping breakfast can be considered a type of IF depending on the fasting hours, as IF diets consist of $\geq 12 \mathrm{~h} /$ day of fasting [4].

Along these lines, IF emerged as a multifaceted dietary tool to manage cardiometabolic problems such as dyslipidemia, elevated blood glucose levels, hypertension, and nonalcoholic fatty liver disease $[5,6]$. Taken together, the mechanisms ascribed to these benefits are mainly due to the fasting-induced adenosine monophosphate-activated protein kinase (AMPK)/sirtuin 1 axis, whose enzymes activate the peroxisome proliferator-activated receptor alpha $(\operatorname{PPAR} \alpha)$ and peroxisome proliferator-activated receptor-gamma coactivator 1 alpha (PGC-1 $\alpha$ ) in skeletal muscle, adipocytes, cardiomyocytes, and hepatocytes, ultimately enhancing fatty acid oxidation and insulin sensitivity [7-11].

Thanks to these attractive mechanisms, IF has also gained massive attention as a weight loss approach, since the AMPK-sirtuin 1 signalizing pathway is triggered by energy depletion [12-14]. However, it is crucial to note that weight loss per se can ameliorate metabolic aspects of cardiovascular diseases and accompanying low-grade inflammation [15-20]. Thus, a critical appraisal geared toward the general effects of IF regimens on weight loss must be done in an effort to draw pragmatic conclusions for scientists, dietitians, physicians, and other health practitioners.

Although epidemiologically relevant and ubiquitous in the general circles of medicine, body weight, body mass index, and waist circumference are measures with less specificity than body fat in understanding adiposity. In this way, clinical attention to body fat changes is a straightforward and meaningful way of inferring weight loss success, guiding professionals who cope with body composition. In 2018, I published a review regarding the general effects of IF on fat mass [21], and, fortunately, many studies were published after that [22-24]. Accordingly, in this brief review, I have updated my previous search and expanded the general effects of IF strategies on fat mass in order to underpin the current scientific state and depict the clinical magnitude. 


\section{Methods}

A brief literature search was performed employing MEDLINE, EMBASE, SCOPUS, and Web of Science from inception to December 2021. The following keywords were used: "intermittent fasting" OR "time-restricted feeding" OR "alternate-day fasting" OR "Ramadan" and "fat mass" OR "weight loss" OR "body composition".

Only human studies were selected, while studies that used skinfold as a method of body composition were excluded due to notable interrater differences. Then, intragroup differences for body fat in kilograms or percentages from IF interventions were collected to provide a clear message. Following this search, a total of 20 arms (17 studies) were included.

Lastly, a viewpoint along with take-home messages for practitioners was undertaken as a means of translating the results into the clinical setting.

\section{Effects of IF Diets on Fat Mass}

Overall, studies in Table 1 that demonstrate significant intragroup decreases in fat mass cover a range of 0.7 to $11.3 \mathrm{~kg}$ after IF regimens, in which the length of interventions varied from two weeks to one year.

Table 1. Human studies that addressed changes in fat mass after intermittent fasting.

\begin{tabular}{|c|c|c|c|c|c|}
\hline Reference & $\begin{array}{l}\text { Subjects in } \\
\text { the IF Arm }\end{array}$ & IF Protocol & Duration & $\Delta$ Fat Mass & $\begin{array}{l}\text { Body } \\
\text { Composition } \\
\text { Method }\end{array}$ \\
\hline \multicolumn{6}{|c|}{ Alternate-day fasting } \\
\hline Carter et al., 2019 [25] & $\begin{array}{l}70 \text { patients with type } \\
2 \text { diabetes ( } 39 \text { women } \\
\text { and } 31 \text { men), } 61 \pm 9 y\end{array}$ & $\begin{array}{c}\text { Followed a 500-600 kcal diet for } \\
2 \text { non-consecutive days/week and their } \\
\text { usual diet for } 5 \text { days/week. }\end{array}$ & 12 months & $\downarrow 5.1 \mathrm{~kg} *$ & DXA \\
\hline Antoni et al., 2018 [26] & $\begin{array}{l}15 \text { patients with } \\
\text { overweight/obesity } \\
\text { ( } 8 \text { women and } \\
7 \text { men), } 42 \pm 4 y\end{array}$ & $\begin{array}{l}\text { Approximately } 25 \% \text { ( } 630 \mathrm{kcal}) \text { of their } \\
\text { estimated energy needs for } \\
2 \text { days / week. } \\
\text { On the remaining } 5 \text { days (feed days), } \\
\text { participants' food intake was } \\
\text { self-selected, but they were asked to } \\
\text { consume a eucaloric healthy diet. }\end{array}$ & 2 weeks & $\downarrow 3.7 \mathrm{~kg} *$ & BIA \\
\hline Byrne et al., 2018 [27] & $\begin{array}{l}24 \text { men with obesity, } \\
40 \pm 9 y\end{array}$ & $\begin{array}{l}\text { Energy intake equivalent to } 67 \% \text { of } \\
\text { weight maintenance requirements. }\end{array}$ & 4 months & $\downarrow 9.2 \mathrm{~kg}$ * & BIA \\
\hline Coutinho et al., 2018 [28] & $\begin{array}{l}18 \text { patients with } \\
\text { obesity (women:men } \\
\text { ratio }=10: 4) \\
39 \pm 11 \mathrm{y}\end{array}$ & $\begin{array}{l}\text { Patients underwent } 3 \text { non-consecutive } \\
\text { days of partial fasting per week ( } 550 \\
\text { and } 660 \mathrm{kcal} / \text { day for women and men, } \\
\text { respectively). For the feeding days, a } \\
\text { diet matching energy needs } \\
\text { was prescribed. }\end{array}$ & 3 months & $\downarrow 11.3 \mathrm{~kg} *$ & Plethysmography \\
\hline $\begin{array}{c}\text { Trepanowski et al., } 2017 \\
\text { [29] }\end{array}$ & $\begin{array}{l}25 \text { men with obesity, } \\
\qquad 44 \pm 10 \mathrm{y}\end{array}$ & $\begin{array}{l}\text { Alternate-day fasting ( } 25 \% \text { of energy } \\
\text { needs on fast days instructed to be } \\
\text { consumed between } 12 \text { p.m. and } 2 \text { p.m.; } \\
\text { 125\% of energy needs on alternating } \\
\text { feast days). }\end{array}$ & 6 months & $\downarrow 4.8 \mathrm{~kg} *$ & DXA \\
\hline Klempel et al., 2013 [30] & $\begin{array}{l}17 \text { women with } \\
\text { obesity, } 42 \pm 3 y\end{array}$ & $\begin{array}{c}\text { Alternate-day fasting, high-fat diet } \\
\text { ( } 45 \% \text { fat, } 40 \% \text { carbohydrate and } 15 \% \\
\text { protein), } 25 \% \text { of energy needs on the } \\
\text { fasting day (consumed between } 12 \text { p.m. } \\
\text { and } 2 \text { p.m.) and } 125 \% \text { of energy needs } \\
\text { on the feed day. }\end{array}$ & 2 months & $\downarrow 5.4 \mathrm{~kg} *$ & DXA \\
\hline Klempel et al., 2013 [30] & $\begin{array}{l}18 \text { women with } \\
\text { obesity, } 43 \pm 2 y\end{array}$ & $\begin{array}{c}\text { Alternate-day fasting, low-fat diet } \\
\text { (25\% fat, } 60 \% \text { carbohydrate and } 15 \% \\
\text { protein), } 25 \% \text { of energy needs on the } \\
\text { fasting day (consumed between } 12 \text { p.m. } \\
\text { and } 2 \text { p.m.) and } 125 \% \text { of energy needs } \\
\text { on the feed day. }\end{array}$ & 2 months & $\downarrow 4.2 \mathrm{~kg} *$ & DXA \\
\hline
\end{tabular}


Table 1. Cont.

\begin{tabular}{|c|c|c|c|c|c|}
\hline Reference & $\begin{array}{l}\text { Subjects in } \\
\text { the IF Arm }\end{array}$ & IF Protocol & Duration & $\Delta$ Fat Mass & $\begin{array}{l}\text { Body } \\
\text { Composition } \\
\text { Method }\end{array}$ \\
\hline \multicolumn{6}{|c|}{ Ramadan } \\
\hline Nachvak et al., 2018 [31] & $\begin{array}{l}152 \text { healthy men, } \\
39 \pm 11 \text { y }\end{array}$ & $\begin{array}{l}\text { Absence of any food or fluid intake } \\
\text { during daylight hours. }\end{array}$ & 1 months & $\downarrow 0.7 \mathrm{~kg} *$ & BIA \\
\hline Hammouda et al., 2013 [32] & $\begin{array}{c}15 \text { professional soccer } \\
\text { players, } 17 \pm 0.3 \mathrm{y}\end{array}$ & $\begin{array}{l}\text { Absence of any food or fluid intake } \\
\text { during daylight hours. }\end{array}$ & 1 month & $\downarrow 0.7 \mathrm{~kg}$ & BIA \\
\hline Mirzaei et al., 2012 [33] & $\begin{array}{l}14 \text { male collegiate } \\
\text { wrestlers, } 20 \pm 3 \mathrm{y}\end{array}$ & $\begin{array}{l}\text { Absence of any food or fluid intake } \\
\text { during daylight hours. }\end{array}$ & 1 month & $\downarrow 1.0 \mathrm{~kg} *$ & BIA \\
\hline Sadiya et al., 2011 [34] & $\begin{array}{l}19 \text { patients } \\
(14 \text { women and } \\
5 \text { men }) \text { with } \\
\text { metabolic syndrome, } \\
37 \pm 13 \mathrm{y}\end{array}$ & $\begin{array}{l}\text { Absence of any food or fluid intake } \\
\text { during daylight hours. }\end{array}$ & 1 month & $\downarrow 0.8 \mathrm{~kg}$ & BIA \\
\hline Ibrahim et al., 2008 [35] & $\begin{array}{l}14 \text { subjects ( } 9 \text { men } \\
\text { and } 4 \text { healthy } \\
\text { women), 25-58 y }\end{array}$ & $\begin{array}{l}\text { Absence of any food or fluid intake } \\
\text { during daylight hours. }\end{array}$ & 1 month & $\uparrow 0.4 \mathrm{~kg}$ & BIA \\
\hline Kassab et al., 2003 [36] & $\begin{array}{l}6 \text { eutrophic women, } \\
18-45 \mathrm{y}\end{array}$ & $\begin{array}{l}\text { Absence of any food or fluid intake } \\
\text { during daylight hours. }\end{array}$ & 1 month & $\downarrow 3.6 * \mathrm{~kg}$ & BIA \\
\hline Kassab et al., 2003 [36] & $\begin{array}{l}18 \text { women with } \\
\text { obesity, } 18-45 \mathrm{y}\end{array}$ & $\begin{array}{l}\text { Absence of any food or fluid intake } \\
\text { during daylight hours. }\end{array}$ & 1 month & $\downarrow 0.2 \mathrm{~kg}$ & BIA \\
\hline \multicolumn{6}{|c|}{ Time-restricted feeding } \\
\hline Pureza et al., 2021 [37] & $\begin{array}{l}31 \text { low-income } \\
\text { women with obesity, } \\
32 \pm 7 \mathrm{y}\end{array}$ & $\begin{array}{l}\text { Low-energy (500-1000 caloric deficit), } \\
\text { time-restricted feeding of } 12 \mathrm{~h} .\end{array}$ & 12 months & $\downarrow 1.0 \%$ & BIA \\
\hline Lowe et al., 2020 [38] & $\begin{array}{l}49 \text { women and men } \\
\text { with overweight and } \\
\text { obesity, } 47 \pm 11 \mathrm{y}\end{array}$ & $\begin{array}{l}\text { Time-restricted eating, ad libitum intake } \\
\text { from } 12 \text { p.m. until } 8 \text { p.m. and complete } \\
\text { abstention from caloric intake from } \\
8 \text { p.m. until } 12 \text { p.m. the following day. }\end{array}$ & 3 months & $\downarrow 0.5 \mathrm{~kg}$ & DXA \\
\hline Moro et al., 2020 [39] & $\begin{array}{l}8 \text { young elite male } \\
\text { cyclists, } 20 \pm 2 y\end{array}$ & $\begin{array}{l}\text { Time-restricted feeding with } 100 \% \text { of the } \\
\text { estimated daily energy needs in an } 8 \text {-h } \\
\text { time window (from } 10 \text { a.m. to } 6 \text { p.m.). }\end{array}$ & 1 month & $\downarrow 1.1 \%$ * & BIA \\
\hline Tinsley et al., 2019 [40] & $\begin{array}{l}13 \text { resistance-trained } \\
\text { females, } 22 \pm 2 \text { y }\end{array}$ & $\begin{array}{l}\text { Time-restricted feeding }(16 / 8) \text { with } \\
\text { calorie intake }(\sim 1600 \mathrm{kcal} / \text { day }) \text { between } \\
12 \text { p.m. to } 8 \text { p.m. }\end{array}$ & 2 months & $\downarrow 0.4 \mathrm{~kg} *$ & DXA \\
\hline Tinsley et al., 2019 [40] & $\begin{array}{l}13 \text { resistance-trained } \\
\text { females, } 22 \pm 3 \mathrm{y}\end{array}$ & $\begin{array}{l}\text { Time-restricted feeding }(16 / 8) \text { with } \\
\text { calorie intake }(\sim 1500 \mathrm{kcal} / \text { day }) \text { between } \\
12 \text { p.m. and } 8 \text { p.m. plus } 3 \text { g/day } \\
\beta \text {-hydroxy } \beta \text {-methylbutyrate. }\end{array}$ & 2 months & $\downarrow 0.7 \mathrm{~kg} *$ & DXA \\
\hline Moro et al., 2016 [41] & $\begin{array}{l}17 \text { resistance-trained } \\
\text { males, } 30 \pm 4 \mathrm{y}\end{array}$ & $\begin{array}{l}\text { Time-restricted feeding }(16 / 8) \text { based on } \\
3 \text { meals consumed at } 1 \text { p.m., } 4 \text { p.m. and } \\
8 \text { p.m. Eucaloric, high-protein diet. }\end{array}$ & 2 months & $\downarrow 1.6 *$ & DXA \\
\hline
\end{tabular}

* statistical intragroup significance $(p<0.05)$ before and after IF as used in the original study; intragroup statistical analysis was not performed for values without superscript symbols. Fat mass values without symbols represent nonsignificant changes. BIA, bioelectrical impedance; DXA, dual-energy X-ray absorptiometry; IF, intermittent fasting.

Regarding methods for assessing fat mass, the use of bioelectrical impedance was prevalent in Ramadan studies, which are the seminal works (2003-2013) in the background of IF (Table 1).

While Ramadan studies have an observational design, fortunately, several randomized clinical trials (RCTs) employing time-restricted feeding or alternate-day fasting have emerged in recent years using dual-energy X-ray absorptiometry (DXA) for body composition analysis (Table 1).

A single study used air displacement plethysmography and, interestingly, showed a greater fat mass reduction $(-11.3 \mathrm{~kg})$ [28]. This study investigated an alternate-day fasting protocol with a duration of three months, in which patients followed three nonconsecutive days of partial fasting per week (550 and $660 \mathrm{kcal} /$ day for women and men, 
respectively) or a diet matching energy needs for feeding days. Such a fat mass loss portrays clinical relevance if maintained in the long term, as epidemiological estimates show that a predicted fat mass above $21 \mathrm{~kg}$ is associated with an overt increase of all-cause mortality risk, confirmed by a hazard ratio of 1.22 (1.18 to 1.26) per standard deviation [42].

As the above-mentioned results are based on intragroup comparisons of IF regimens, it is crucial to consider their effects compared to continuous energy restriction. Trepanowski et al. conducted one of the best RCTs so far to respond to this clinical question [29]. Both alternate-day fasting ( $25 \%$ and $125 \%$ of energy needs on fast days and feast days, respectively) and continuous energy restriction ( $75 \%$ of energy needs every day) decreased the fat mass in patients with obesity under a 6-month weight-loss phase, without difference between groups [29]. Therefore, it cannot be affirmed that IF regimes are superior to traditional low-calorie diets, especially when calories are equalized.

\section{General Clues for Clinical Practice}

Individuals with obesity can benefit from IF due to its greater flexibility. For instance, it is possible to maintain high-volume meals within the eating window, which could be an interesting approach for individuals with obesity due to a likely higher stomach capacity induced by previous eating habits [43].

At least $\sim 30$ g protein per meal (or $\sim 3 \mathrm{~g}$ leucine across food per meal) divided into two high-volume meals with one or two snacks can be sufficient to supply total protein needs, aiding satiety and muscle maintenance as well [41,44-46]. Supplementing with whey protein or vegetable protein (i.e., pea, soy, and rice protein isolate) along with dairy (yogurt, milk, cheese, etc.) can be useful tools for providing an adequate amount of protein and calcium in snacks. This advice is important because the central tenet of IF is to reduce the meal frequency, thereby decreasing the intake of dietary sources of calcium by excluding breakfast and snacks.

It is worth noting that it is wise to include high-fiber foods in high-volume meals in order to avoid excess calories from sugars and oils. Vegetables, fruits, seeds, whole grains are some examples of healthy foods to be included as a base. In addition, they provide micronutrients and antioxidants [47-51]. That said, incorporating small amounts of "unhealthy" foods can be accepted to maintain some of the patient's habits, but in moderation, as flexible dieting strategies have been deemed an important weight loss approach as a means of avoiding weight regain [52].

Binge eating in patients with obesity must be monitored individually. On the one hand, IF could shorten the eating window, leading to a reduced total caloric intake; on the other hand, long hours of fasting could trigger binge eating and therefore result in a higher caloric intake even within the eating window of IF regimens.

Nowadays, due to a busy work schedule, many individuals only have the early morning hours to exercise. Thus, IF can be an approach to not shortening the hours of sleep to prepare breakfast and wait for a proper digestion time; however, exercise while fasting can be uncomfortable for many individuals, although it is metabolically viable given that muscle glycogen stores depend on the previous day's food intake [53] and a common exercise routine ( $1 \mathrm{~h} /$ day) does not cause hypoglycemia [54] —except in patients on hypoglycemic medications without adequate control [55].

Finally, caveats for different clinical populations cannot be ruled out. Not only patients with insulin-treated diabetes but also very elderly subjects, children, and pregnant and breastfeeding women can be more susceptible to adverse effects of fasting.

\section{Conclusions}

IF regimens are a useful tool targeting weight loss due to their pronounced body fatlowering effects. In addition to aesthetic outcomes, these effects in part explain the benefits of IF in obesity-related diseases (e.g., dyslipidemia, type 2 diabetes mellitus, hypertension, and nonalcoholic fatty liver disease) due to the unifying link between adiposity and low- 
grade inflammation [2,56], but further long-term RCTs are imperative to allow a better understanding of dietary adherence and primary outcomes.

At best, health professionals (dietitians, nutritionists, and physicians) who face miscellaneous challenges in the inherently complex management of obesity could consider IF diets as a worthwhile strategy. Notwithstanding the attractive mechanisms and clinical results, however, the benefits of IF diets occur thanks to energy restriction and thus cannot be considered the best dietary protocol compared to conventional methods.

Funding: H.O.S. has been supported by the Coordenação de Aperfeiçoamento de Pessoal de Nível Superior-Brazil (CAPES).

Institutional Review Board Statement: Not applicable.

Informed Consent Statement: Not applicable.

Data Availability Statement: Not applicable.

Conflicts of Interest: The author declares no conflict of interest.

\section{References}

1. Patterson, R.E.; Laughlin, G.A.; LaCroix, A.Z.; Hartman, S.J.; Natarajan, L.; Senger, C.M.; Martinez, M.E.; Villasenor, A.; Sears, D.D.; Marinac, C.R.; et al. Intermittent Fasting and Human Metabolic Health. J. Acad. Nutr. Diet. 2015, 115, 1203-1212. [CrossRef] [PubMed]

2. Kord, H.V.; Tinsley, G.M.; Santos, H.O.; Zand, H.; Nazary, A.; Fatahi, S.; Mokhtari, Z.; Salehi-Sahlabadi, A.; Tan, S.C.; Rahmani, J.; et al. The influence of fasting and energy-restricted diets on leptin and adiponectin levels in humans: A systematic review and meta-analysis. Clin. Nutr. 2021, 40, 1811-1821. [CrossRef]

3. Meng, H.; Zhu, L.; Kord-Varkaneh, H.; Santos, H.O.; Tinsley, G.M.; Fu, P. Effects of intermittent fasting and energy-restricted diets on lipid profile: A systematic review and meta-analysis. Nutrition 2020, 77, 110801. [CrossRef]

4. Santos, H.O.; Genario, R.; Macedo, R.C.O.; Pareek, M.; Tinsley, G.M. Association of breakfast skipping with cardiovascular outcomes and cardiometabolic risk factors: An updated review of clinical evidence. Crit. Rev. Food Sci. Nutr. 2020, 62, 466-474. [CrossRef] [PubMed]

5. Malinowski, B.; Zalewska, K.; Wesierska, A.; Sokolowska, M.M.; Socha, M.; Liczner, G.; Pawlak-Osinska, K.; Wicinski, M. Intermittent Fasting in Cardiovascular Disorders-An Overview. Nutrients 2019, 11, 673. [CrossRef]

6. Crupi, A.N.; Haase, J.; Brandhorst, S.; Longo, V.D. Periodic and Intermittent Fasting in Diabetes and Cardiovascular Disease. Curr. Diabetes Rep. 2020, 20, 83. [CrossRef] [PubMed]

7. Bujak, A.L.; Crane, J.D.; Lally, J.S.; Ford, R.J.; Kang, S.J.; Rebalka, I.A.; Green, A.E.; Kemp, B.E.; Hawke, T.J.; Schertzer, J.D.; et al AMPK activation of muscle autophagy prevents fasting-induced hypoglycemia and myopathy during aging. Cell Metab. 2015, 21, 883-890. [CrossRef]

8. Kajita, K.; Mune, T.; Ikeda, T.; Matsumoto, M.; Uno, Y.; Sugiyama, C.; Matsubara, K.; Morita, H.; Takemura, M.; Seishima, M.; et al. Effect of fasting on PPARgamma and AMPK activity in adipocytes. Diabetes Res. Clin. Pract. 2008, 81, 144-149. [CrossRef]

9. Canto, C.; Auwerx, J. PGC-1alpha, SIRT1 and AMPK, an energy sensing network that controls energy expenditure. Curr. Opin. Lipidol. 2009, 20, 98-105. [CrossRef]

10. Lee, W.J.; Kim, M.; Park, H.S.; Kim, H.S.; Jeon, M.J.; Oh, K.S.; Koh, E.H.; Won, J.C.; Kim, M.S.; Oh, G.T.; et al. AMPK activation increases fatty acid oxidation in skeletal muscle by activating PPARalpha and PGC-1. Biochem. Biophys. Res. Commun. 2006, 340, 291-295. [CrossRef]

11. Macedo, R.C.O.; Santos, H.O.; Tinsley, G.M.; Reischak-Oliveira, A. Low-carbohydrate diets: Effects on metabolism and exercise-A comprehensive literature review. Clin. Nutr. ESPEN 2020, 40, 17-26. [CrossRef]

12. Welton, S.; Minty, R.; O’Driscoll, T.; Willms, H.; Poirier, D.; Madden, S.; Kelly, L. Intermittent fasting and weight loss: Systematic review. Can. Fam. Physician Med. Fam. Can. 2020, 66, 117-125.

13. Rynders, C.A.; Thomas, E.A.; Zaman, A.; Pan, Z.; Catenacci, V.A.; Melanson, E.L. Effectiveness of Intermittent Fasting and Time-Restricted Feeding Compared to Continuous Energy Restriction for Weight Loss. Nutrients 2019, 11, 2442. [CrossRef] [PubMed]

14. Patterson, R.E.; Sears, D.D. Metabolic Effects of Intermittent Fasting. Annu. Rev. Nutr. 2017, 37, 371-393. [CrossRef] [PubMed]

15. Santos, H.O.; Lavie, C.J. Weight loss and its influence on high-density lipoprotein cholesterol (HDL-C) concentrations: A noble clinical hesitation. Clin. Nutr. ESPEN 2021, 42, 90-92. [CrossRef]

16. Santos, H.O.; Earnest, C.P.; Tinsley, G.M.; Izidoro, L.F.M.; Macedo, R.C.O. Small dense low-density lipoprotein-cholesterol (sdLDL-C): Analysis, effects on cardiovascular endpoints and dietary strategies. Prog. Cardiovasc. Dis. 2020, 63, 503-509. [CrossRef] [PubMed]

17. Santos, H.O.; Kones, R.; Rumana, U.; Earnest, C.P.; Izidoro, L.F.M.; Macedo, R.C.O. Lipoprotein(a): Current Evidence for a Physiologic Role and the Effects of Nutraceutical Strategies. Clin. Ther. 2019, 41, 1780-1797. [CrossRef] [PubMed] 
18. Santos, H.O.; Penha-Silva, N. Translating the advanced glycation end products (AGEs) knowledge into real-world nutrition strategies. Eur. J. Clin. Nutr. 2021, 1-7. [CrossRef]

19. Sohouli, M.H.; Fatahi, S.; Sharifi-Zahabi, E.; Santos, H.O.; Tripathi, N.; Lari, A.; Pourrajab, B.; Kord-Varkaneh, H.; Gaman, M.A.; Shidfar, F. The Impact of Low Advanced Glycation End Products Diet on Metabolic Risk Factors: A Systematic Review and Meta-Analysis of Randomized Controlled Trials. Adv. Nutr. 2020, 12, 766. [CrossRef] [PubMed]

20. Lari, A.; Sohouli, M.H.; Fatahi, S.; Cerqueira, H.S.; Santos, H.O.; Pourrajab, B.; Rezaei, M.; Saneie, S.; Rahideh, S.T. The effects of the Dietary Approaches to Stop Hypertension (DASH) diet on metabolic risk factors in patients with chronic disease: A systematic review and meta-analysis of randomized controlled trials. Nutr. Metab. Cardiovasc. Dis. NMCD 2021, 31, 2766-2778. [CrossRef]

21. Santos, H.O.; Macedo, R.C.O. Impact of intermittent fasting on the lipid profile: Assessment associated with diet and weight loss. Clin. Nutr. ESPEN 2018, 24, 14-21. [CrossRef]

22. Karras, S.N.; Koufakis, T.; Adamidou, L.; Dimakopoulos, G.; Karalazou, P.; Thisiadou, K.; Makedou, K.; Zebekakis, P.; Kotsa, K Implementation of Christian Orthodox fasting improves plasma adiponectin concentrations compared with time-restricted eating in overweight premenopausal women. Int. J. Food Sci. Nutr. 2021, 1-11. [CrossRef]

23. Karras, S.N.; Koufakis, T.; Adamidou, L.; Polyzos, S.A.; Karalazou, P.; Thisiadou, K.; Zebekakis, P.; Makedou, K.; Kotsa, K. Similar late effects of a 7-week orthodox religious fasting and a time restricted eating pattern on anthropometric and metabolic profiles of overweight adults. Int. J. Food Sci. Nutr. 2021, 72, 248-258. [CrossRef] [PubMed]

24. Karras, S.N.; Koufakis, T.; Adamidou, L.; Antonopoulou, V.; Karalazou, P.; Thisiadou, K.; Mitrofanova, E.; Mulrooney, H.; Petroczi, A.; Zebekakis, P.; et al. Effects of orthodox religious fasting versus combined energy and time restricted eating on body weight, lipid concentrations and glycaemic profile. Int. J. Food Sci. Nutr. 2021, 72, 82-92. [CrossRef] [PubMed]

25. Carter, S.; Clifton, P.M.; Keogh, J.B. The effect of intermittent compared with continuous energy restriction on glycaemic control in patients with type 2 diabetes: 24-month follow-up of a randomised noninferiority trial. Diabetes Res. Clin. Pract. 2019, 151, 11-19. [CrossRef]

26. Antoni, R.; Johnston, K.L.; Collins, A.L.; Robertson, M.D. Intermittent v. continuous energy restriction: Differential effects on postprandial glucose and lipid metabolism following matched weight loss in overweight/obese participants. Br. J. Nutr. 2018, 119, 507-516. [CrossRef] [PubMed]

27. Byrne, N.M.; Sainsbury, A.; King, N.A.; Hills, A.P.; Wood, R.E. Intermittent energy restriction improves weight loss efficiency in obese men: The MATADOR study. Int. J. Obes. 2018, 42, 129-138. [CrossRef]

28. Coutinho, S.R.; Halset, E.H.; Gasbakk, S.; Rehfeld, J.F.; Kulseng, B.; Truby, H.; Martins, C. Compensatory mechanisms activated with intermittent energy restriction: A randomized control trial. Clin. Nutr. 2018, 37, 815-823. [CrossRef]

29. Trepanowski, J.F.; Kroeger, C.M.; Barnosky, A.; Klempel, M.C.; Bhutani, S.; Hoddy, K.K.; Gabel, K.; Freels, S.; Rigdon, J.; Rood, J.; et al. Effect of Alternate-Day Fasting on Weight Loss, Weight Maintenance, and Cardioprotection Among Metabolically Healthy Obese Adults: A Randomized Clinical Trial. JAMA Intern. Med. 2017, 177, 930-938. [CrossRef]

30. Klempel, M.C.; Kroeger, C.M.; Varady, K.A. Alternate day fasting increases LDL particle size independently of dietary fat content in obese humans. Eur. J. Clin. Nutr. 2013, 67, 783-785. [CrossRef]

31. Nachvak, S.M.; Pasdar, Y.; Pirsaheb, S.; Darbandi, M.; Niazi, P.; Mostafai, R.; Speakman, J.R. Effects of Ramadan on food intake, glucose homeostasis, lipid profiles and body composition composition. Eur. J. Clin. Nutr. 2019, 73, 594-600. [CrossRef] [PubMed]

32. Hammouda, O.; Chtourou, H.; Aloui, A.; Chahed, H.; Kallel, C.; Miled, A.; Chamari, K.; Chaouachi, A.; Souissi, N. Concomitant effects of Ramadan fasting and time-of-day on apolipoprotein AI, B, Lp-a and homocysteine responses during aerobic exercise in Tunisian soccer players. PLoS ONE 2013, 8, e79873. [CrossRef]

33. Mirzaei, B.; Rahmani-Nia, F.; Moghadam, M.G.; Ziyaolhagh, S.J.; Rezaei, A. The effect of ramadan fasting on biochemical and performance parameters in collegiate wrestlers. Iran. J. Basic Med. Sci. 2012, 15, 1215-1220. [PubMed]

34. Sadiya, A.; Ahmed, S.; Siddieg, H.H.; Babas, I.J.; Carlsson, M. Effect of Ramadan fasting on metabolic markers, body composition, and dietary intake in Emiratis of Ajman (UAE) with metabolic syndrome. Diabetes Metab. Syndr. Obes. Targets Ther. 2011, 4 , 409-416. [CrossRef]

35. Ibrahim, W.H.; Habib, H.M.; Jarrar, A.H.; Al Baz, S.A. Effect of Ramadan fasting on markers of oxidative stress and serum biochemical markers of cellular damage in healthy subjects. Ann. Nutr. Metab. 2008, 53, 175-181. [CrossRef] [PubMed]

36. Kassab, S.E.; Abdul-Ghaffar, T.; Nagalla, D.S.; Sachdeva, U.; Nayar, U. Serum leptin and insulin levels during chronic diurnal fasting. Asia Pac. J. Clin. Nutr. 2003, 12, 483-487. [PubMed]

37. de Oliveira Maranhao Pureza, I.R.; da Silva Junior, A.E.; Silva Praxedes, D.R.; Lessa Vasconcelos, L.G.; de Lima Macena, M.; Vieira de Melo, I.S.; de Menezes Toledo Florencio, T.M.; Bueno, N.B. Effects of time-restricted feeding on body weight, body composition and vital signs in low-income women with obesity: A 12-month randomized clinical trial. Clin. Nutr. 2021, 40, 759-766. [CrossRef]

38. Lowe, D.A.; Wu, N.; Rohdin-Bibby, L.; Moore, A.H.; Kelly, N.; Liu, Y.E.; Philip, E.; Vittinghoff, E.; Heymsfield, S.B.; Olgin, J.E.; et al. Effects of Time-Restricted Eating on Weight Loss and Other Metabolic Parameters in Women and Men with Overweight and Obesity: The TREAT Randomized Clinical Trial. JAMA Intern. Med. 2020, 180, 1491-1499. [CrossRef]

39. Moro, T.; Tinsley, G.; Longo, G.; Grigoletto, D.; Bianco, A.; Ferraris, C.; Guglielmetti, M.; Veneto, A.; Tagliabue, A.; Marcolin, G.; et al. Time-restricted eating effects on performance, immune function, and body composition in elite cyclists: A randomized controlled trial. J. Int. Soc. Sports Nutr. 2020, 17, 65. [CrossRef] 
40. Tinsley, G.M.; Moore, M.L.; Graybeal, A.J.; Paoli, A.; Kim, Y.; Gonzales, J.U.; Harry, J.R.; VanDusseldorp, T.A.; Kennedy, D.N.; Cruz, M.R. Time-restricted feeding plus resistance training in active females: A randomized trial. Am. J. Clin. Nutr. 2019, 110, 628-640. [CrossRef] [PubMed]

41. Moro, T.; Tinsley, G.; Bianco, A.; Marcolin, G.; Pacelli, Q.F.; Battaglia, G.; Palma, A.; Gentil, P.; Neri, M.; Paoli, A. Effects of eight weeks of time-restricted feeding $(16 / 8)$ on basal metabolism, maximal strength, body composition, inflammation, and cardiovascular risk factors in resistance-trained males. J. Transl. Med. 2016, 14, 290. [CrossRef] [PubMed]

42. Lee, D.H.; Keum, N.; Hu, F.B.; Orav, E.J.; Rimm, E.B.; Willett, W.C.; Giovannucci, E.L. Predicted lean body mass, fat mass, and all cause and cause specific mortality in men: Prospective US cohort study. BMJ 2018, 362, k2575. [CrossRef]

43. Geliebter, A. Stomach capacity in obese individuals. Obes. Res. 2001, 9, 727-728. [CrossRef]

44. Paddon-Jones, D.; Westman, E.; Mattes, R.D.; Wolfe, R.R.; Astrup, A.; Westerterp-Plantenga, M. Protein, weight management, and satiety. Am. J. Clin. Nutr. 2008, 87, 1558S-1561S. [CrossRef] [PubMed]

45. Jager, R.; Kerksick, C.M.; Campbell, B.I.; Cribb, P.J.; Wells, S.D.; Skwiat, T.M.; Purpura, M.; Ziegenfuss, T.N.; Ferrando, A.A.; Arent, S.M.; et al. International Society of Sports Nutrition Position Stand: Protein and exercise. J. Int. Soc. Sports Nutr. 2017, 14, 20. [CrossRef]

46. Teixeira, F.J.; Santos, H.O.; Howell, S.L.; Pimentel, G.D. Whey protein in cancer therapy: A narrative review. Pharmacol. Res. 2019, 144, 245-256. [CrossRef]

47. Santos, H.O.; Teixeira, F.J.; Schoenfeld, B.J. Dietary vs. pharmacological doses of zinc: A clinical review. Clin. Nutr. 2019, 39, 1345-1353. [CrossRef] [PubMed]

48. Santos, H.O.; Price, J.C.; Bueno, A.A. Beyond Fish Oil Supplementation: The Effects of Alternative Plant Sources of Omega-3 Polyunsaturated Fatty Acids upon Lipid Indexes and Cardiometabolic Biomarkers-An Overview. Nutrients 2020, $12,3159$. [CrossRef] [PubMed]

49. Santos, H.O.; Macedo, R.C.O. Cocoa-induced (Theobroma cacao) effects on cardiovascular system: HDL modulation pathways. Clin. Nutr. ESPEN 2018, 27, 10-15. [CrossRef] [PubMed]

50. Harasym, J.; Oledzki, R. Effect of fruit and vegetable antioxidants on total antioxidant capacity of blood plasma. Nutrition 2014, 30, 511-517. [CrossRef]

51. Santos, H.O.; Genario, R.; Gomes, G.K.; Schoenfeld, B.J. Cherry intake as a dietary strategy in sport and diseases: A review of clinical applicability and mechanisms of action. Crit. Rev. Food Sci. Nutr. 2020, 61, 417-430. [CrossRef] [PubMed]

52. Conlin, L.A.; Aguilar, D.T.; Rogers, G.E.; Campbell, B.I. Flexible vs. rigid dieting in resistance-trained individuals seeking to optimize their physiques: A randomized controlled trial. J. Int. Soc. Sports Nutr. 2021, 18, 52. [CrossRef]

53. Murray, B.; Rosenbloom, C. Fundamentals of glycogen metabolism for coaches and athletes. Nutr. Rev. 2018, 76, 243-259. [CrossRef]

54. Dohm, G.L.; Beeker, R.T.; Israel, R.G.; Tapscott, E.B. Metabolic responses to exercise after fasting. J. Appl. Physiol. 1986, 61, 1363-1368. [CrossRef]

55. Cockcroft, E.J.; Narendran, P.; Andrews, R.C. Exercise-induced hypoglycaemia in type 1 diabetes. Exp. Physiol. 2020, 105, 590-599. [CrossRef] [PubMed]

56. Wang, X.; Yan, Q.; Liao, Q.; Li, M.; Zhang, P.; Santos, H.O.; Kord-Varkaneh, H.; Abshirini, M. Effects of intermittent fasting diets on plasma concentrations of inflammatory biomarkers: A systematic review and meta-analysis of randomized controlled trials. Nutrition 2020, 79-80, 110974. [CrossRef] [PubMed] 